$1-1-2013$

\title{
You Can't Get There from Here: Elderly Prisoners, Prison Downsizing, and the Insufficiency of Cost Cutting Advocacy
}

\author{
Elizabeth Rapaport \\ University of New Mexico - School of Law
}

Follow this and additional works at: https://digitalrepository.unm.edu/law_facultyscholarship

Part of the Elder Law Commons, and the Law and Society Commons

\section{Recommended Citation \\ Elizabeth Rapaport, You Can't Get There from Here: Elderly Prisoners, Prison Downsizing, and the Insufficiency of Cost Cutting Advocacy, Unpublished Working Paper (2013). \\ Available at: https://digitalrepository.unm.edu/law_facultyscholarship/239}

This Working Paper is brought to you for free and open access by the UNM School of Law at UNM Digital Repository. It has been accepted for inclusion in Faculty Scholarship by an authorized administrator of UNM Digital Repository. For more information, please contact amywinter@unm.edu, Isloane@salud.unm.edu,

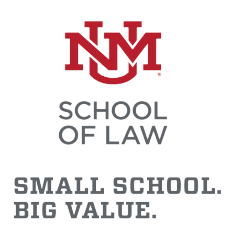

BIG VALUE. 


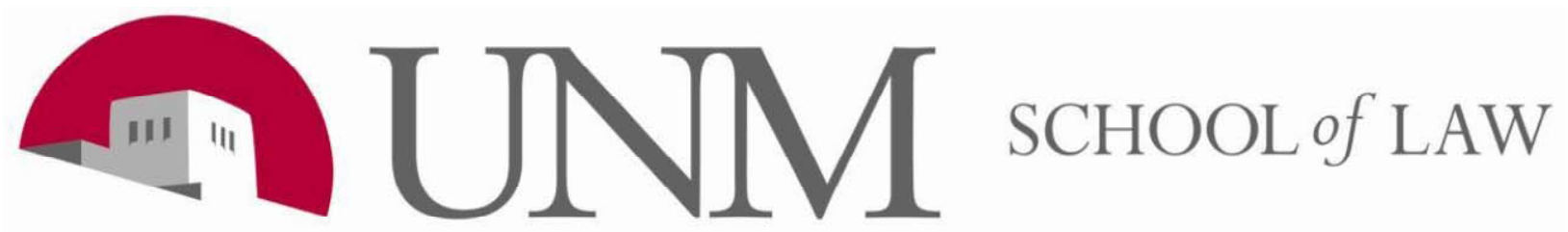

\title{
UNIVERSITY OF NEW MEXICO SCHOOL OF LAW LEGAL STUDIES RESEARCH PAPER SERIES
}

\author{
PAPER NO. 2013-07
}

\section{You Can't Get There from Here: Elderly Prisoners, Prison Downsizing, and the Insufficiency of Cost Cutting Advocacy}

\author{
Elizabeth Rapaport
}

April 21, 2013

Founded in 1947, the University of New Mexico School of Law is a vibrant, diverse community of outstanding faculty, students, and alumni who are making a difference across the country and around the world. The School, which offers a rich and engaged classroom experience guided by faculty members who are leaders in their fields, is an "acknowledged" leader in the fields of clinical education, American Indian law, and natural resources and environmental law. The University of New Mexico School of Law Legal Studies eJournal contains abstracts, works in progress, and published papers from our faculty. For more information see: http://lawschool.unm.edu. 
You Can't Get There From Here: Elderly Prisoners, Prison Downsizing, and the Insufficiency of Cost Cutting Advocacy

\author{
Elizabeth Rapaport \\ Professor of Law \\ University of New Mexico \\ rapaport@law.unm.edu
}

\begin{abstract}
The prison population in the United States has peaked and begun to recede, reversing more than 30 years of growth. ${ }^{1}$ Mass incarceration is yielding to the imperative to reduce state budgets in recessionary times. As states turn away from the extravagant use of prison for nonviolent offenders, the percentage of the prison population serving long and life sentences for violent felonies will increase. By 2009 one in eleven prisoners were lifers. ${ }^{2}$ These are the prisoners growing old and dying in prison. High cost elderly prisoners who have aged out of crime should be good candidates for cost saving measures such as compassionate release, parole, and release through community corrections programs. This impression does not withstand scrutiny. Two thirds of elderly prisoners have been convicted of violent crimes; one quarter has been convicted of sexual offenses. ${ }^{3}$ Programs to reduce prison costs have indeed gained ground but they are designed for a very different population. The offender who is well positioned to avoid or leave prison as a result of cost savings policies is a young nonviolent offender; The majority of states have succeeded in reducing prison admissions by diverting nonviolent offenders to drug and other treatment programs and reducing prison terms for low level offenders. ${ }^{4} \mathrm{~A}$ threshold condition for diversion or release is low risk of violent offending. Implicitly these low risk nonviolent offenders are also promoted as criminals who can rehabilitate and reintegrate into the community. The majority of compassionate release programs either exclude prisoners who were convicted of violent crimes or require that the prisoner be incapacitated to the extent that he or she poses no threat to public safety. ${ }^{5}$ Yet even prisoners who meet these standards are rarely released. Arguing for cost cutting release of the fast growing legion of elderly prisoners is much less easily buttressed with soothing claims about the happy coincidence of lower costs and public safety. Even if, and it is big if, exaggerated fear of
\end{abstract}

\footnotetext{
1 The Bureau of Justice Statistics reports that 2010 marked the first time since 1972 that there was a decline in the total number of prisoners in state and federal prisons. BUREAU OF JUST. STAT., U.S. DEP'T OF JUST., PRISONERS IN 20101 (2011), available at http://www.bjs.gov/content/pub/pdf/p10.pdf. The decline continued in 2011. BUREAU OF JuST. STAT., U.S. DEP'T OF JUST., PRISONERS IN 20111 (2012), available at http://www.bjs.gov/content/pub/pdf/p11.pdf.

${ }^{2}$ Ashley Nellis and Ryan S. King, The Sentencing Project, No Exit: The Expanding Use of Life Sentences in AMERICA 6 (2009).

${ }^{3}$ HUM. RTS. WATCH, supra note 4, at 30.

${ }^{4}$ Pew Charitable Trusts, Public Safety Performance Project, U.S. Prison Count Continues to Drop, http://www.pewstates.org/news-room/press-releases/us-prison-count-continues-to-drop-85899457496 (last visited Apr. 17, 2013).

${ }^{5}$ VERA INST. OF JUST., supra note 19 , at 7.
} 
further predations were successfully addressed, ${ }^{6}$ the advocate of cost cutting reform cannot answer demands for retribution without venturing beyond the discourse of the "tough on crime" era. For thirty years the political class has shunned the previously commonly invoked criminal justice values of second chances -- the redemptive values of rehabilitation, reintegration, and mercy. The sickest and oldest prisoners are largely beyond second chances for productive citizenship. Whether released or incarcerated their care will be borne by the public purse. ${ }^{7}$ Elder care is not free. ${ }^{8}$ This Article focuses on the subclass of old prisoners who are beyond any prospect for productive citizenship because of age and ill health and are in need of elder care. The argument of this Article is that in order to capture the savings that release (and efficient carceral care) of elderly prisoners would bring, politicians and policy advocates will have to relearn to speak the language of humane criminal justice values, prominently mercy.

A sixty-six year old double amputee robbed a bank. He rolled into the bank in a wheelchair wielding a sawed off shotgun. He had been released from a Michigan prison three weeks prior to the robbery. ${ }^{9}$

\section{Cost Cutting Arguments Alone Fail to Make the Case for Alleviating the Fiscal Burden of Incarcerating Elderly}

Legislators and policy makers face the daunting task of cutting corrections costs swollen by three decades of mass incarceration policies ${ }^{10}$ in an era of constricting state budgets. Having promoted hundreds of laws that lengthened sentences or time served --

\footnotetext{
${ }^{6}$ Id. at 3-5.

${ }^{7}$ Release of indigent aged prisoners typically involves shifting costs from corrections budgets to the budgets of other state agencies and the federal government. VERA INST. OF JUST., IT'S ABOUT TIME: AGING PRISONERS, INCREASING COSTS AND GERIATRIC RELEASE 8 (2010), available at http://www.vera.org/sites/default/files/resources/downloads/Its-about-time-aging-prisoners-increasingcosts-and-geriatric-release.pdf.

8 Anno et al., Correctional Health Care, supra note 5; Jonathan Turley, Op-Ed, An "Old" Prison Solution, L.A. TimEs, Oct. 7, 2006, at B17; Heather Habes, Paying for the Graying: How California Can More Effectively Manage Its Growing Elderly Inmate Population, 20 S. CAL. INTERDISC. L.J. 395, 395 (2011).

9 Timothy Curtin ${ }_{\llcorner}$The Continuing Problem of America's Aging Prison Population and the Search for a CostEffective and Socially Acceptable Means of Addressing It, 15 ELDER baw-L_.Journal_. 473, 499 (2007). 10 See generally, Jennifer WARren, Pew Center on the States, Pub. SAFety PerformanCe Project, One in 100: BEHIND BARS IN AMERICA 2008 (2008), available at http://www.pewstates.org/uploadedFiles/PCS_Assets/2008/one\%20in\%20100.pdf [hereinafter BEHIND BARS]; DAVID GARLAND, THE CUlTURE OF CONTROL (2001); Adam Liptak, Inmate Count in U.S. Dwarfs Other Nations', N.Y. TIMES, Apr. 23, 2008, at A1.
} 
life without parole, habitual offender, elimination of parole --, public officials now seek to reduce the burden these and other mass incarceration policies impose on the public fisc. ${ }^{11}$

Mass incarceration policies in the United States have resulted in a sharp increase in the population of elderly prisoners. ${ }^{12}$ In the ten year period 2000-2010 there has been a threefold rise in the number of prisoners 55 years of age and older in state and federal prison. ${ }^{13}$ Contributing to the increase in the aged population is that life expectancy for all Americans has risen, ${ }^{14}$ supported by medical advances. ${ }^{15}$ Criticism of prison health care notwithstanding, ${ }^{16}$ access to modern medicine behind bars is keeping prisoners alive longer. Although as our population ages more persons in their 50's and older ages are going to prison, these statistics reflect the steep increases in prisoners serving life sentences and long terms of years, and the diminished availability of parole. ${ }^{17}$ Estimates of the proportion of old prisoners by the year 2020 range from one fifth to nearly one third. ${ }^{18}$ The majority of states have succeeded in reducing prison admissions by diverting nonviolent offenders to drug and other treatment programs and reducing prison terms for

\footnotetext{
${ }^{11}$ Editorial, Shrinking Prisons, Saving Billions, N.Y. TImEs, Mar. 3, 2013, at SR12; Pew Charitable Trusts, Public Safety Performance Project, Infographic, More Than Half of States Cut Imprisonment Rates 2009-2011, U.S. PRISON COUNT CONTINUES TO DROP, http://www.pewstates.org/news-room/press-releases/us-prison-countcontinues-to-drop-85899457496 (last visited Apr. 17, 2013).

12 From 2007-2010, there was a 63\% increase in the number of state and federal prisoners who were 65 years of age or older. Hum. RTS. WATCh, Old Behind BARS: The Aging PRison Population of the United States 18 (2012), available at http://www.hrw.org/sites/default/files/reports/usprisons0112webwcover_0.pdf. 13 The National Commission on Correctional Health Care uses age 55 as the lower bound of "old" or "elderly" for the inmate population because inmates enjoy relatively poor health at entry and prison conditions are inimical to good health. JAYE ANNO ET AL., U.S. DEP'T OF JUST., NAT'L INST. OF CORRECTIONS, CORRECTIONAL HEALTH CARE: AdDRESSing THE NEEDS OF THE EldERlY, Chronicially ILL, AND TERMinAlly Ill INMATES (2004), available at http://static.nicic.gov/Library/018735.pdf.

${ }_{14}$ R.V. Rikard \& Ed Rosenberg, Aging Inmates: A Convergence of Trends in the American Criminal Justice System, 13 Journal of Correctional Heath Care 150, 151 (June 2007).

15 Id.

${ }^{16}$ Brown v. Plata, 131 S. Ct. 1910 (2011), provides extensive documentation of health care failures in California prisons.

${ }^{17}$ Hum. RTS. Watch, supra note 4, at 24-9; AnNo Et AL., CoRRECTIONAL HEAlth CARE, supra note 5, at 7-8.

${ }^{18}$ Rikard \& Rosenberg, supra note 6, at 151.
} 
low level offenders. ${ }^{19}$ The prison population in the United States has peaked and begun to recede, reversing a 30 years of growth. ${ }^{20}$ As states turn away from the extravagant use of prison for nonviolent offenders, the percentage of the prison population serving long and life sentences for violent felonies will further increase. Currently one in eleven prisoners are lifers. ${ }^{21}$ These are the prisoners that grow old and die in prison.

As a class prisoners in old age exhibit three characteristics: 1 ) They are at low risk to recidivate.22 2) They are more than twice as expensive to incarcerate as younger prisoners because of their health and general frailty. ${ }^{23} 3$ ) Designed for the young, prison imposes hardships on prisoners suffering from the chronic illnesses and physical and mental deterioration that beset old age. ${ }^{24}$ This profile suggests opportunities for downsizing that reach beyond avoiding initiating drug users and the mentally ill into careers of multiple imprisonments. Cash strapped states could reduce their prison budgets by parole release or compassionate release of some of this fast growing legion of aged prisoners.

\footnotetext{
19 Pew Charitable Trusts, Public Safety Performance Project, U.S. Prison Count Continues to Drop, http://www.pewstates.org/news-room/press-releases/us-prison-count-continues-to-drop-85899457496 (last visited Apr. 17, 2013).

20 The Bureau of Justice Statistics reports that 2010 marked the first time since 1972 that there was a decline in the total number of prisoners in state and federal prisons. BUREAU OF JUST. STAT., U.S. DEP'T OF JUST., PRISONERS IN 20101 (2011), available at http://www.bjs.gov/content/pub/pdf/p10.pdf. The decline continued in 2011. BUREAU OF JUST. STAT., U.S. DEP'T OF JUST., PRISONERS IN 20111 (2012), available at http://www.bjs.gov/content/pub/pdf/p11.pdf.

${ }^{21}$ Ashley nellis and Ryan S. King, The Sentencing Project, No Exit: The Expanding Use of Life Sentences in AMERICA 6 (2009).

22 There is an inverse relationship between the age at which a prisoner is released and the rate of recidvisim.BJS DOJ, Recidivism of Prisoners Released in 1994 at 7. A study conducted by the Florida Department of Corrections found that compared to younger prisoners, prisoners 50 and older, had lower rates of recidivism and those 65 and older more markedly lower rates. FLORIDA DEPARTMENT OF CORRECTIONS, 2009 FLORIDA PRISON RECIDIVISM STUDY: RELEASES FROM 2001 TO 200816 (2010), available athttp://www.dc.state.fl.us/secretary/press/2010/recidivismstudy.pdf.

${ }^{23}$ Anno cites estimates that place incarceration of the incarceration of the elderly on average between $\$ 60,000$ and $\$ 70,000$, as compared with $\$ 27,000$ for younger inmates. ANNo ET AL., CoRRECTIONAL HEAlth CARE, supra note 5 , at 11 .

${ }^{24}$ See infra Section II, Old in America's Prisons.
} 
However, the formula that has served reform advocates well in the case of diversion or reduced time in prison for nonviolent offenders, offers little chance of success with the old. That seductive formula is that greater public safety can be purchased at lower cost. ${ }^{25}$ Advocates urge the happy coincidence of public safety and cost saving. However, the old in prison are largely persons who committed violent offenses that inspire fear and strong moral condemnation. Arguing for cost savings reforms from which this population would benefit is much less easily buttressed with soothing claims about enhanced public safety. Even if, and it is big if, exaggerated fear of predation were successfully addressed, ${ }^{26}$ the advocate of cost cutting reform cannot address demands for retribution within the discourse of the "tough on crime" era. For thirty years the political class has shunned the previously commonly invoked criminal justice values of second chances -- the redemptive values of rehabilitation, reintegration, and mercy. The cupboard of morally authoritative and persuasive arguments in support of reform is not bare, but some useful staples have been languishing in its dark recesses. Just as bad or worse from the perspective of cost cutting, the sickest and oldest prisoners are in any case largely beyond second chances for productive citizenship. Whether released or incarcerated their care will be borne by the public purse..$^{27}$ Elder care is not free. ${ }^{28}$ This Article will focus on the subclass of old

\footnotetext{
25 See Pew Center on the States, Prison Count 2010: State Population Declines for the First Time in 38 Years 3 (2010), available at: http://www.pewtrusts.org/uploadedFiles/wwwpewtrustsorg/Reports/sentencing_and_corrections/Prison_ Count_2010.pdf.

${ }^{26} I d$. at 3-5.

${ }^{27}$ Release of indigent aged prisoners typically involves shifting costs from corrections budgets to the budgets of other state agencies and the federal government. VERA INST. OF JUST., IT'S ABOUT TIME: AGING PRISONERS, INCREASING COSTS AND GERIATRIC RELEASE 8 (2010), available at http://www.vera.org/sites/default/files/resources/downloads/Its-about-time-aging-prisoners-increasingcosts-and-geriatric-release.pdf.

${ }^{28}$ Anno et Al., Correctional Health Care, supra note 5; Jonathan Turley, Op-Ed, An "Old" Prison Solution, L.A. TimEs, Oct. 7, 2006, at B17; Heather Habes, Paying for the Graying: How California Can More Effectively Manage Its Growing Elderly Inmate Population, 20 S. CAL. INTERDISC. L.J. 395, 395 (2011).
} 
prisoners who are beyond any prospect for productive citizenship because of age and ill health and are in need of elder care. Natural processes and current sentencing policies will inexorably swell their ranks. There are of course younger violent offenders who are serving long sentences well beyond the point of an efficient cost for gains in public safety; cost savings advocacy for evaluating this population for release is the more frustrated because the demand for incapacitation is not fatuous. If it is to be met it and must be by credibly invoking redemptive criminal justice values. Cost cutters will need to venture beyond "tough on crime" and cost efficiency to achieve cost efficiency in this domain.

Reformers are caught in the dilemma of unsustainable costs and countervailing extravagant demands for public safety and retribution. In the case of elderly prisoners, a solution lies in going between the horns of the dilemma. Public advocacy for reform can rely on the reinvigoration of an array of criminal justice values long dormant that can ally with cost efficiency. Both compassionate release programs and improved carceral care present opportunities for cost efficiency but also require allocating resources to a reviled prison population.

The recent U.S Supreme Court case of Brown v. Plata may raise expectations that the federal courts will help to dissolve the dilemma by mandating reduction in prison populations and improvements in prison health care. ${ }^{29}$ Brown v. Plata held that California could not achieve constitutionally mandated improvements in its woefully deficient prison health care system unless it decreased the population in its severely overcrowded prisons. The decision commands downsizing and increased spending on health care. Prison health care reform has the potential to be of particular benefit to aged inmates. However,

${ }^{29} 131$ S. Ct 1910 (2011). 
reformers should not place excessive reliance on allies on the federal courts. Plata's reaffirmation of prisoners' Eighth Amendment right to adequate health care is certainly encouraging. However, prisoner protection under the Eighth Amendment has a meandering history, the more expansive interpretations yielding to modest at best protections of prisoners. ${ }^{30}$ Its benevolent light has yet to shine on aged prisoners per se.

I have no quarrel with the soundness of cost/benefit arguments advanced in support of the release or improved carceral care for elderly prisoners. ${ }^{31}$ My quarrel is rather with the expectation that these arguments alone can either justify reform on behalf of elderly prisoners or win the day in the political arena. There are of course good reasons to shy away from all but cost and public safety arguments. Mercy and compassion, like rehabilitation, have had little political resonance in public discourse about crime and punishment in the past thirty years. ${ }^{32}$ The revitalization of public crime and punishment philosophy would take courage on the part of members of the political class. My claim is that this renovation of public philosophy is necessary for downsizing enterprise to achieve its potential, not that it is easily achieved.

Efficiency arguments may succeed in reducing reliance on prison as a method of combating nonviolent crime without revising three decades of reliance on incapacitation,

\footnotetext{
${ }^{30}$ See infra Section IV Prison Geriatric Care and the Eighth Amendment.

31 VERA INST. OF JUST., supra note 19, at 10; HUM. RTS. WATCH, supra note 4; Habes, supra note 20; Curtin, supra note 1.

${ }^{32} \mathrm{~A}$ recent illustrative indication of the current state of public discourse on crime and punishment is the furor that erupted when Mississippi Governor Haley Barbour granted clemency to five murderers who were trusties working at the governor's mansion. Trusty releases are a time honored practice. Barbour stoutly defended his actions: "I have so much confidence that I allowed my grandchildren to play with those five men." Despite Barbour's popularity, the press and popular response was outrage. Jessica Bakeman, Barbour: Forgive, Cut Medical Costs, CLARION LEDGER, Jan. 13, 2012, http://www.clarionledger.com/article/20120114/NEWS01/201140348/Barbour-Forgive-cut-medical-costs.
} 
deterrence and retribution as the goals of American criminal justice. ${ }^{33}$ But elderly

prisoners are more likely than younger prisoners to have been convicted of violent crimes;

nearly two thirds of state prisoners fifty-five and older are serving sentences for violent

crimes. ${ }^{34}$ Those convicted of violent crimes are not good candidates for early release

programs. ${ }^{35}$ Murderers, for example, have low recidivism rates, ${ }^{36}$ but as a class they are

not targeted for cost saving release. They inspire public fear and loathing.

Consider the nearly ubiquitous programs for compassionate release of the disabled and dying (regardless of age). ${ }^{37}$ They are severely underused. ${ }^{38}$ After 30 years in which harsh retribution and incapacitation have dominated public discourse about crime and punishment, compassionate release looks politically toxic, however fiscally sensible and innocuous to public safety. This hesitation to release high cost prisoners who are more profoundly incapacitated by their health than by prison walls tells us something. The extreme caution with which compassionate release is approached suggests that even the terminally ill, much more so the relatively healthy elderly prisoner, if convicted of a violent

\footnotetext{
${ }^{33}$ Franklin ZimRing \& GoRdon HaWkins, InCAPACITATION (1995); Jonathan Simon, Governing Through CRime (2007).

${ }^{34}$ Hum. RTS. WATCH, supra note 4 , at 30.

35 'All the public opinion polls say that everybody will reconsider sentencing for nonviolent offenders or drug offenders, but they are not willing to do anything different for violent offenders." Solomon Moore, Study Finds Record Number of Inmates Serving Life, N.Y. TIMES, July 23, 2009, A24, quoting Stanford criminology professor Joan Petersilia. "In fact, [Petersilia] added, polls show support for even harsher sentences for sex offenses and other violent crimes." Id.

36 BuREau of Just. Stat., U.S. DeP’t OF JustiCE, ReCidivism OF Prisoners RELEASED in 1994 (2002), available at http://www.bjs.gov/content/pub/pdf/rpr94.pdf.

37 "Compassionate release" is a comprehensive term referring to a variety of parole procedures addressed to disabled, severely or terminally ill, or dying prisoners of any age or restricted age. Compassionate parole is sometimes available for other than health related reasons. Marjorie P. Russell, Too Little, Too Late, Too Slow, Compassionate Release of Terminally Ill Prisoners: Is the Cure Worse than the Disease?, 3 WIDENER J. OF PUB. L. 799, 806-7 (1994). Old, ill and dying prisoners are sometimes also the beneficiaries of executive clemency. Id. at 822-3. According to this widely cited 1994 survey, all but three states have some mechanism for compassionate release. Id. at 819-20. The recent Vera Institute of Justice survey found fifteen states and the District of Columbia have release procedures that "specifically target older inmates" or have "added agespecific criteria" to more inclusive compassionate release procedures. VERA INST. OF JUST., supra note 19, at 6. ${ }^{38}$ Russell, supra note 29. The Vera Institute concludes "geriatric release programs have had little impact." VERA INST. OF JUST., supra note 19, at 6.
} 
crime, are understood by corrections authorities and the political class as an object of public antipathy. The same antipathy may put obstacles in the path of cost efficient humane prison elder care because it resembles, as it must, elder care for the "deserving" elderly in the free world.

Successful fiscal reform may well require braiding arguments for cost reduction and "smart on crime" policies of crime reduction with advocacy for tempering harsh retribution. Further, it may require acknowledging that tempering justice with mercy or compassion is a legitimate element of American criminal justice. The political class may have to justify compassion for the undeserving. By the "undeserving elderly" I understand here prisoners who may have nothing to recommend them for compassionate treatment other than their age and infirmities. The undeserving elderly prisoner has not distinguished him or herself in any of the ways that American criminal justice sometimes recognizes as earning relief from the rigors of an original sentence. ${ }^{39}$ Such prisoners may not have undergone moral reform or distinguished themselves through contributions to prison society. They may simply have grown old.

\section{Old in America's prisons}

Old people in prison serve hard time. Old age in prison is calculated to commence at 55 or earlier because prisoners are 10 or 15 years ahead of the free population in the progress of the decline experienced by aging free Americans. ${ }^{40}$ The toll of prison conditions is a factor in this accelerated decline as is the poor health of this population at entry. ${ }^{41}$

\footnotetext{
39 On the distinction between deserving and earning leniency, see Elizabeth Rapaport, Retribution and Redemption in the Operation of Executive Clemency, 74 CHI-KENT L. REV. 1501(2000).

40 Anno et AL., CoRrectional Health CARE, supra note 5, at 8-9; Vera InST. of JUST., supra note 19.

41 Poverty, unhealthy habits and substandard medical care prior to incarceration contribute to the deficits prisoners bring with them to prison. HUM. RTS. WATCH, supra note 4, at 18.
} 
Prison architecture and prison life are designed for a young. ${ }^{42}$ The pace and discipline of prison life are hard on those who are slow in body and mind, whose mobility is compromised, whose sight and hearing are impaired, who suffer more from cold and heat, and who on average suffer from three chronic ailments. ${ }^{43}$ The elderly are prey for younger prisoners. ${ }^{44}$ There is a discernible trend of managing the aged population by segregating them in dedicated facilities where they can more efficiently and humanely be cared for. ${ }^{45}$ Segregated or mainstreamed, cost efficient or inefficient, today's prisons are elder care facilities.

\section{Cost only advocacy: the elephants in the room}

In more than three decades of "Penal Populism," 46 the American public has been schooled to respond to criminals with fear and loathing, especially to violent criminals. "Penal Populism" sums up the politics and policies characteristic of this period: Politicians wrested crime and punishment from the professional elites who had dominated policy earlier in the $20^{\text {th }}$ century. As crime rates rose in the 1970 s and 80 s, the political class made electoral hay out of crime control policies that abandoned rehabilitation, the dominant penal ideology at midcentury, in favor of retributive punishment and incapacitation. Three decades on, states can no longer afford Penal Populism and mass

\footnotetext{
42 "The physical plants commonly found in correctional facilities were designed for young and physically active inmates. Living units and support service buildings are scattered over wide areas, and inmates must walk long distances for meals, medical services...Poor ventilation and climate control can be extremely hard on the elderly. Kenneth L. Faivor, ed., Special Issues in Aging, in HEALth CARE MANAGEMENT IN CoRRECTIONS, quoted in ANNO ET AL., CORRECTIONAL HEALTH CARE, supra note 5, at 30.

43 Gross, supra note 21, at 59-61; ANNO ET AL., CoRRECTIONAL HeAlth CARE, supra note 5, at 17-25.

${ }^{44}$ HUM. RTS. WATCH, supra note 4, at 57-60; Gross, supra note 21, at 60.

${ }^{45}$ Anno et al., Correctional Health Care, supra note 5, at, Chapter IV, Program, Housing, and Treatment Considerations, at 29-43.

46 JOHN PRATT, PENAL POPULISM (2007).
} 
incarceration. But advocates of downsizing are constrained by the continuing momentum of Penal Populism. We have little recent experience with public advocacy of criminal justice values that allow criminals their humanity, redemptive values such as rehabilitation that dominated corrections philosophy in the mid $20^{\text {th }}$ century. Cost reduction arguments in this environment look politically tenable only when cost savings do not challenge demands for retribution and public safety.

High cost elderly prisoners who have aged out of crime should be good candidates for cost saving efficiencies. This impression does not withstand scrutiny. Two thirds of elderly prisoners have been convicted of violent crimes; one quarter has been convicted of sexual offenses. ${ }^{47}$ Programs to reduce prison costs have indeed gained ground but they are designed for a very different population. The offender who is well positioned to benefit from cost savings policies is a young nonviolent offender; in at least 13 states such low risk criminals are being diverted to drug courts and community corrections rather than being sent to prison..$^{48}$ A threshold condition for diversion is low risk of violent offending. It is proving to be possible to revalorize rehabilitation for nonviolent offenders. Implicitly these low risk nonviolent offenders are also promoted as criminals who can be redeemed and reintegrated into the community. The threshold for compassionate release from prison is considerably higher than that which must be met in order to avoid embarking on a prison career through diversion: pose no risk to public safety. The majority of compassionate release programs either exclude prisoners who were convicted of violent crimes or require that the prisoner be incapacitated to the extent that he or she poses no threat to public

\footnotetext{
${ }^{47}$ HUM. RTS. WATCH, supra note 4 , at 30.

${ }^{48}$ BEHIND BARS, supra note 2, at 18.
} 
safety. ${ }^{49}$ Yet even prisoners who meet these standards are rarely released. The barriers to release are fear and antipathy: The public is concerned, for example, that if admitted into nursing homes and other elder care facilities that serve the free aged, terminally ill and disabled offenders will prey upon other patients. ${ }^{50}$ This public resistance, and the specter of a septuagenarian Willie Horton, apparently explains the failure to implement compassionate release programs. If prisoners whose condition is dire are too frightening to release, we should not entertain expectations of expansion of compassionate release programs to include healthier old prisoners.

Free or in custody elderly prisoners will be supported by public funds. The great majority of released elderly offenders are shifted from correctional budgets to state or federal social welfare budgets. ${ }^{51}$ Very few long incarcerated elderly have family willing or able to assume their care. From a social point of view, the cost savings produced by release programs are partially illusory. Some long incarcerated prisoners do not wish to be released, as they have nowhere to go and fear life outside prison walls. My suspicion is that the same antipathy that leads to resistance to the release of terminally prisoners would fuel opposition to cost efficient spending, to provide humane geriatric prison care. Penal Populism has not prepared the public to support the murderer or the pedophile in enjoying a level of care that equals or perhaps exceeds that accessible to free persons of small means.

\section{Prison Geriatric Care and the Eighth Amendment}

\footnotetext{
${ }^{49}$ VERA INST. OF JUST., supra note 19 , at 7.

${ }^{50} I d$. at 8.

${ }^{51} \mathrm{Id}$.
} 
The Eight Amendment underwrites prisoners' rights to medical care and the satisfaction of other "basic needs." ${ }^{2}$ The incarcerated must rely on prison authorities for the provision of basic needs since they cannot provide for themselves. ${ }^{53}$ The Supreme Court relies on two fundamental Eighth Amendment doctrines to arrive at the conclusion that the Constitution grounds these prisoners' rights. The Eighth Amendment's prohibition of cruel and unusual punishment is not exhausted by torture and barbaric treatment but has long been held to ban prison cruelty that fails to comport with "evolving standards of decency that mark the progress of a maturing society." 54 The Eighth Amendment bars the infliction of "unnecessary suffering," understood as suffering that serves no "penological purpose." 55 Thus, the Eighth Amendment bars failure to provide medical care and fulfill other basic needs that cause suffering other than the suffering incident to lawful sentences, which we will presume are not themselves cruel and unusual in the terms of the Eight Amendment.

A generous reading of the application of these doctrines to prison elder care would perhaps lead to the result that prison elders are entitled to a standard of care similar to that provided to elders in the free world. Such elder care might be held to be the standard embraced by contemporary society. That standard of care could be mandated to avoid penologically extraneous suffering resulting from age and infirmity rather than suffering dictated by the terms of a sentence. The potential for such a reading might be encouraged by the history of willingness on the part of the federal courts to intervene massively to

\footnotetext{
${ }^{52}$ Estelle v. Gamble, 429 U.S. 97 (1976).

${ }^{53}$ Id. at 103-4.

${ }^{54} I d$. at 102.

${ }^{55} \mathrm{Id}$. at 103.
} 
ameliorate prison conditions and enforce the constitutional guarantee of medical care in prisons. ${ }^{56}$

Such an interpretation is certainly possible. It would bring the Eighth Amendment into alignment with contemporary human rights norms and the correctional practices of the other common law countries and Europe. However, there is a tension in the Supreme Court's prisoners' rights cases between language that suggests a generous standard for provision of prisoners' "basic needs" and a constricted, minimalist understanding of what satisfies the Constitution. To date, the minimalist reading has prevailed in the prisoners' rights cases. Prisoners are entitled only to "the minimal civilized measure of life's necessities." 57 The basic needs that have been vouchsafed are "food, warmth, and exercise," ${ }^{58}$ medical care, ${ }^{59}$ sanitation. ${ }^{60}$ We are reminded in Wilson v. Seiter that the Constitution "does not mandate comfortable prisons" 61 and that only deprivations of basic needs that result from "deliberate indifference" to prisoner's distress rise to the level of Eighth Amendment violations.

Whether confined for a year or forty years, "essential food, medical care or sanitation,"62 offers a meager conception of the fulfillment of basic human needs. The needs of elderly prisoners are greater or in any event different from those of their juniors. Their medical care needs are constant not episodic. They are more burdened with ailments, disabilities, failing senses and general frailty than most of their juniors. Unless

\footnotetext{
${ }^{56}$ Brown v. Plata is the culminating example of federal court intervention, requiring the state of California to release over 30,000 prisoners within 2 years because due to chronic severe overcrowded the state has failed to provide medical care. $131 \mathrm{~S}$. Ct. 1910.

${ }^{57}$ Rhodes v. Chapman, 452 U.S. 337, 347(1981).

58 Wilson v. Seiter, 501 U.S. 294, 304 (1991).

${ }^{59} \mathrm{Id}$. at 300.

${ }^{60}$ Rhodes, 452 U.S. at 348.

${ }^{61}$ Wilson v. Seiter, 501 U.S. 294, 298 (1991).

${ }^{62}$ Rhodes, 452 U.S. at 347-8.
} 
accommodation is made, these general conditions of age add layers of physical and mental suffering to prison life. Should accommodating prison elders constitute an appropriate interpretation of Eighth Amendment "basic needs" for this population or a vain demand for "comfortable prisons?" Is the suffering of frail elder bodies and minds in prison without "penological purpose" or rather part and parcel of any sentence long enough to portend aging and dying in prison? Thus far the generous potential of the Eighth Amendment has not been realized for prisoners, prison elders included.

The Eighth Amendment has merely supplied a floor below which federal and state prison conditions may not fall. The most recent Supreme Court prisoners' rights case illustrates the reluctance of the Court to venture beyond minimalist conception of prisoners' Eighth Amendment rights. The Court in Brown v. Plata was provoked to order tens of thousands of prisoners be sent to county jails, out of state prisons, or released to relieve prison overcrowding. ${ }^{63}$ The Court concluded that extreme overcrowded conditions in California prisons prevented the state from meeting its constitutional obligation to provide adequate medical care to prisoners. ${ }^{64}$ The record before the Court documented that California's failure was both systemic and abject. ${ }^{65}$ The dramatic remedy imposed should not obscure that the Court did not transcend its minimal "essential" medical care model heretofore employed. Rather it provided a bold remedy for the catastrophic failure of the state to provide health care in its chaotic, overcrowded prisons.

\section{Advocating for humane reform: earned and unearned mercy}

${ }^{63}$ Brown v. Plata, 131 S. Ct., at 1922.

${ }^{64} \mathrm{Id}$. at $1923-4$.

${ }^{6} \mathrm{Id}$. at 1939. 
Public antipathy to elderly murderers and pedophiles does not abate simply because the cost of incarcerating them is large and growing. The reformer who pursues greater use of compassionate release and efficient segregated housing for prison elders will be accused of loosing predators and coddling undeserving criminals. Cost savings arguments alone will not persuade politicians or the public to support cost savings programs. Reform could run into the buzz saw of demands for incapacitation and more punitive conditions of incarceration. One option for reformers is obfuscation, to advertise cost savings but conceal risk or any humane improvements in the living conditions of the incarcerated elderly. This approach would be a disheartening continuation of the manipulation that has degraded public discourse and public policy in the mass incarceration era. This approach would of course also place such initiatives and their proponents at risk should humane practices come to light or a disabled septuagenarian find the will and the means to resume predation. An alternative would be to braid cost arguments with the criminal justice values that have been suppressed in public discourse in the mass incarceration era. The redemptive values of rehabilitation, reintegration and mercy could return to public discourse about crime and punishment policies.

It will be useful to distinguish between two types of good reasons that support the reduction of a sentence of imprisonment. These might be called "earned" and "unearned" mercy. By "mercy" here I understand diminution of sentence or the conditions under which the sentence is served for reasons other than legal errors in conviction and sentencing. Granting mercy, earned or unearned, is not the important business of correcting erroneous convictions and sentences but rather taking into account the 
subsequent life course of the prisoner. ${ }^{66}$ A prisoner might earn consideration for parole release by contributions to prison society such as teaching fellow prisoners to read or caring for the sick. Or by acts of heroism such as risking his life to save a guard or fellow prisoner threatened by rioting prisoners or a prison in flames. These achievements or contributions are reasons to be taken into consideration when a prisoner applies for parole or executive clemency. The prisoner earns consideration but has no enforceable claim. ${ }^{67} \mathrm{~A}$ second kind of good reason to show mercy does not arise because of the reform or accrued merit of the prisoner but from his or her physical or mental infirmity and suffering. Such infirmities afflict the prison population in advanced old age and are acerbated by typical prison conditions. The good reason to show unearned mercy is compassion for human suffering. The aged or other afflicted prisoner may not have reformed, rehabilitated or otherwise earned consideration for relief. His or her claim to consideration may reside solely in need and suffering.

For prison elders compassion would be the apposite redemptive value in that active contributions exceeding a pro-social atttitude and cooperativeness may be beyond the capacities of so many of them. The degree or quality of compassion mustered need not approach saintliness. Nor need it be accompanied by forgiveness. What is needed is just enough recognition of the fellow humanity of the elderly criminal to allow comprehension

\footnotetext{
${ }^{66}$ Some proponents of strict retributive justice regard justice as entirely "backward looking;" from this point of view nothing a prisoner does post-conviction ought to reduce his or her sentence. Although certain features of the criminal justice dispensation of the last few decades has moved us closer to this approach, parole, good time, compassionate release and executive clemency are testimony to the lack of fit between this view and American criminal justice institutions. See Rapaport, supra note 31 for a discussion and critique of retributive justice understood in this restrictive form.

${ }^{67}$ If however the prisoner has satisfied requirements which law or regulation treats as sufficient (not merely relevant) for release, he or she would be entitled to release. Conn. Bd. of Pardons v. Dumschat, 452 U.S. 458, 464 (1981).
} 
of the suffering of fellow human beings and appreciation of their dependent state. Return to free society on any terms may lie beyond the current limits of feasible reform for elders who have committed grave offenses. Reintegration into family and community, if feasible at all, would be limited to the settings of a nursing facility or hospice. A pubic commitment to humane treatment of the geriatric prison population would improve the prospects for cost savings through greater use of compassionate release programs and efficient prison geriatric care. To gain cost efficiency we must be willing to acknowledge that the needs and suffering of elderly prisoners is a reason for reform worthy of public support. 